\title{
Acute ischemic stroke thrombi have an outer shell that impairs
}

\section{fibrinolysis}

Neurology ${ }^{\circledR}$ 2019;93:819. doi:10.1212/WNL.0000000000008538

In the article "Acute ischemic stroke thrombi have an outer shell that impairs fibrinolysis" by Di Meglio et al., ${ }^{1}$ first published online September 20, 2019, "n" under the "CE" group in figure 4C should have read $(\mathrm{n}=51)$. The corrected version appears in the October 29 issue. The authors regret the error.

\section{Reference}

1. Di Meglio L, Desilles JP, Ollivier V, et al. Acute ischemic stroke thrombi have an outer shell that impairs fibrinolysis. Neurology 2019;93: e1686-e1698.

\section{Tissue inhibitor metalloproteinase-1 and clinical outcomes after} acute ischemic stroke

Neurology ${ }^{\circledR}$ 2019;93:819. doi:10.1212/WNL.0000000000008564

In the article "Tissue inhibitor metalloproteinase- 1 and clinical outcomes after acute ischemic stroke" by Zhong et al., ${ }^{1}$ first published online September 24,2019 , the grant number associated with the Natural Science Foundation of Jiangsu Province should be BK20190818. The corrected grant number appears in the October 29 issue. The publisher regrets the error.

\section{Reference}

1. Zhong C, Wang G, Xu T, et al. Tissue inhibitor metalloproteinase-1 and clinical outcomes after acute ischemic stroke. Neurology 2019; 93:e1675-e1685. 


\section{Neurology}

Tissue inhibitor metalloproteinase-1 and clinical outcomes after acute ischemic stroke Neurology 2019;93;819

DOI 10.1212/WNL.0000000000008564

This information is current as of October 28, 2019

Updated Information \& Services

References

Permissions \& Licensing

Reprints including high resolution figures, can be found at: http://n.neurology.org/content/93/18/819.2.full

This article cites 1 articles, 1 of which you can access for free at: http://n.neurology.org/content/93/18/819.2.full\#ref-list-1

Information about reproducing this article in parts (figures,tables) or in its entirety can be found online at:

http://www.neurology.org/about/about_the_journal\#permissions

Information about ordering reprints can be found online:

http://n.neurology.org/subscribers/advertise

Neurology ${ }^{\circledR}$ is the official journal of the American Academy of Neurology. Published continuously since 1951, it is now a weekly with 48 issues per year. Copyright (O 2019 American Academy of Neurology. All rights reserved. Print ISSN: 0028-3878. Online ISSN: 1526-632X.



